\title{
Influence of the Frying Recipients in the Quality of Soy and Refined Nhandiroba Vegetable Oils
}

\author{
Lindeberg Rocha Freitas*, Ana Paula Moraes Ventura, Rita de Cássia Ramos do Egypto \\ Queiroga and Marçal de Queiroz Paulo \\ Universidade Federal da Paraíba; João Pessoa - PB - Brasil
}

\begin{abstract}
The main objective of this work was to quantify the migration of iron and aluminium ions and to evaluate the influence of recipients made of iron, stainless steel, aluminium and glass on the oxidative stability during frying with soy (Glycine max) and refined nhandiroba oils (Fevillea trilobata). Soy oil during the frying process in the four distinct recipients presented increased Free Fatty Acids index (FFA) and Peroxide index (PI) values and decreased Iodine index (II) values. Refined nhandiroba oil presented decreased FFA rates in all the recipients investigated. The analysis of results showed that soy oil presented relevant oxidative alterations when compared to the heating time of $72 \mathrm{~h}$ and the types of frying recipients used, and in iron and stainless steel recipients, these differences were higher when compared to glass and aluminium recipients. The analysis of the nhandiroba oil presented moderate oxidative modifications in all the frying recipients investigated.
\end{abstract}

Key words: Vegetal oils, frying, oxidative stability

\section{INTRODUCTION}

The most important industrial and domestic application of vegetal oils is their use in the frying food processes. Frying is a cooking and particularly a process in terms of working temperature where oil is heated in the presence of air and light at temperatures ranging from $160^{\circ} \mathrm{C}$ to $200^{\circ} \mathrm{C}$ for periods of time relatively long. During the frying process, oils are continuously exposed to several factors that lead to a large diversity of chemical reactions, such as, hydrolysis, oxidation and polymerization of the triacylglycerol molecule (Gião, 1999). The oxidation process may be sped up by the presence of metals presenting more than one valence state such as iron and aluminium released from cookery utensils during the frying process. The cooking process develops features such as odor, taste, color and texture that make the food more attractive for consumption (Mogharbel, 2003). The deterioration of the frying oil is generally followed by alterations in its color and in the values of its acidity, iodine and peroxide indexes. The oxidative process depends on the manipulation, processing and storage conditions and on the chemical composition of the oil, once its reactivity increases with the increase in the number of insaturations in the carbon chain of the fat molecule (Yaghmur, 2001). Nhandiroba oil is more resistant to the oxidative process produced by the metallic recipients such as iron, stainless steel, aluminium and others like glass when

\footnotetext{
* Author for correspondence: lindebergrocha@yahoo.com.br
} 
compared to the commercial soy oil, being considered a good alternative as frying oil. However, not many works on the influence of the several types of recipients in the frying procedures on the quality of oils have been published. The main objective of this work was to quantify the migration of iron and aluminium ions and to evaluate the influence of recipients made of iron, stainless steel, aluminium and glass on the oxidative stability process during frying with soy and refined nhandiroba oils (Fevillea trilobata).

\section{MATERIALS AND METHODS}

Commercial soy oil and refined nhandiroba seed oil were submitted to heating at industrial frying temperature $\left(180 \pm 5^{\circ} \mathrm{C}\right)$ using four types of recipients (stainless steel, iron, aluminium and glass) in two samples of $100 \mathrm{ml}$ each. The frying process was performed on a metal plate controlled by a digital thermocouple and an immersion thermometer at atmospheric pressure. The $10 \mathrm{ml}$ oil samples were collected at the following time intervals: $0 \mathrm{~h}, 8 \mathrm{~h}, 24 \mathrm{~h}, 48 \mathrm{~h}$ and $72 \mathrm{~h}$. The thermal stability evaluations of the frying oils were performed through chemical analyses on the content of free fatty acids - FFA $-(\mathrm{mgKOH} / \mathrm{g})$, the iodine index $-\mathrm{II}-\left(\mathrm{gI}_{2} / 100 \mathrm{~g}\right)$ and the peroxide index - PI - (meq $/ \mathrm{kg})$ and analyses of color, performed with a Colorimeter PFX-995. The analyses were determined by the AOAC (2000) in duplicates. The iron ion determination was performed using $2 \mathrm{~g}$ of oil sample submitted to controlled carbonization in a crucible. The sample was initially heated in a Bunsen burner and then in an oven at $600^{\circ} \mathrm{C}$. Concentrated hydrochloric acid was added $(1 \mathrm{ml})$, followed by $10 \mathrm{ml}$ of deionized water that was evaporated in order to achieve a of $\mathrm{pH}$ between 4.0 and 5.0. Samples were diluted in order to obtain the volumes of $50 \mathrm{ml}$, followed by readings in the atomic absorption spectrophotometer (model Perkin-Elmer-503). The aluminium ion determination followed the methodology applied to determination Iron ion and the readings were taken in atomic emission spectrum equipment of inductive coupled plasma spectrometer spectroflame.

\section{Refinement of the Nhandiroba Oil}

It was done Following the methodology proposed by Ogunsua and Badifu (1989).

Statistical Analysis of Results The analyses of results were performed by the means of the SAS statistical program (2003).

\section{RESULTS AND DISCUSSION}

The quality of frying oil samples collected from four different recipients (iron, stainless steel, aluminium and glass) was analysed. The acidity (FFA), peroxide (PI) and iodine (II) indexes, as well as the color of the frying oils changed significantly $(p<0.05)$ as a function of time of frying and the type of recipient, with the exception of the peroxide index that presented no significant variation $(p>0.05)$. The complexity of the frying process generally induces to alterations on the free fatty acids, iodine and peroxide indexes (Moharram and Osman, 1982; Ndjouenkeu and Ngassoum, 2002; Yaghmur et al., 2001; Che man and Jaswir, 1999; Paul and Mittal, 1997). The thermo-oxidative stability of both the frying oils, was evaluated through FFA, II, PI and color values. Which changed as a function of the frying time and type of recipient. The analyses of the FFA values of all oil samples are presented in Table 1 and Figures 1 and 2. The results showed that the FFA rate increased according to a general standard for soy oil samples through the oxidation process. However, the refined nhandiroba oil did not follow such standard. The FFA value found for the soy oil was $650 \%$ lower in glass recipients and $757 \%$ in iron recipients. The refined nhandiroba oil presented a decrease of $50 \%$ on the FFA rate indicating that there was a higher volatilization of these fatty acids produced than those formed during the frying process. The acidity percentile values (FFA) obtained were higher in iron and stainless steel recipients, due to the pro-oxidant power of the metal that migrated to the oil. 
Table 1 - Influence of the frying recipients on the free fatty acids values FFA of soy (Glycine max) and refined nhandiroba (Fevillea trilobata) oils.

\begin{tabular}{clccccc}
\hline & & \multicolumn{5}{c}{ Acidity Index (mg KOH/g oil) } \\
\hline \multicolumn{1}{c}{ Refineds Oils } & Recipients & $\mathbf{0 h}$ & $\mathbf{8 h}$ & $\mathbf{2 4 h}$ & $\mathbf{4 8 h}$ & $\mathbf{7 2 h}$ \\
\hline \multirow{3}{*}{ Soy (Glycine max) } & Glass & 0.14 & 0.14 & 0.42 & 0.98 & 1.05 \\
& Aluminium & 0.14 & 0.28 & 0.42 & 0.85 & 1.10 \\
& Iron & 0.14 & 0.28 & 0.42 & 1.00 & 1.20 \\
& Stainless steel & 0.14 & 0.22 & 0.42 & 0.99 & 1.12 \\
Nhandiroba (Fevillea & Glass & 1.12 & 0.84 & 0.50 & 0.56 & 0.56 \\
trilobata) & Aluminium & 1.12 & 0.84 & 0.56 & 0.56 & 0.56 \\
& Iron & 1.26 & 1.14 & 0.70 & 0.56 & 0.56 \\
& Stainless steel & 1.14 & 1.14 & 0.84 & 0.56 & 0.56 \\
\hline
\end{tabular}

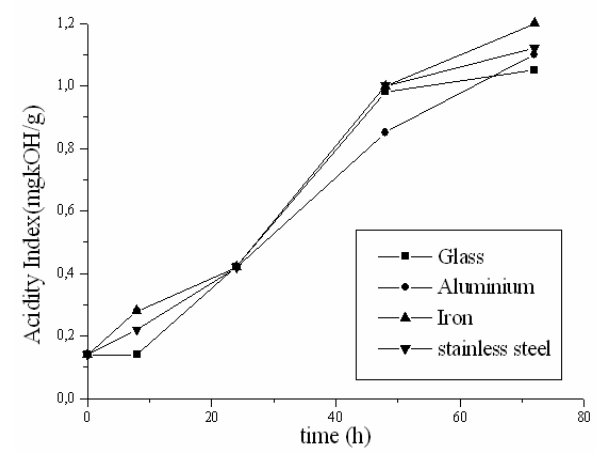

Figure 1 - Influence of the type of frying recipients on the FFA of the soy oil

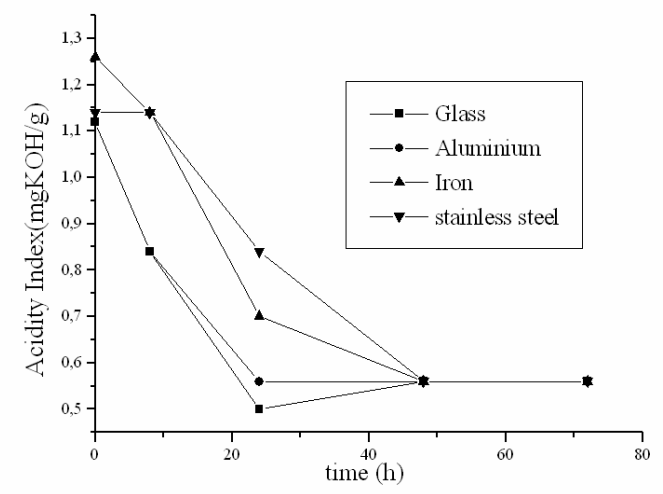

Figure 2 - Influence of the type of frying recipients on the FFA of the nhandiroba oil.

According to Table 2 and Figures 3 and 4, the evaluations of II in both oils led to results of higher iodine rate of the beginning of the frying process, followed by a progressive drop on these values. The variation on the II rate in both oils was lower in glass recipients, followed by aluminium, stainless steel and iron (highest II). Comparing the oils analysed, the refined nhandiroba oil presented the lowest variations of the iodine index rates.
During the frying process, the peroxide index values (PI) were higher in iron recipients and lowest in glass recipients, as shown in Table 3 and Figures 5 and 6 . These results corroborated that refined nhandiroba oil was the most resistant of the two oils analysed to the oxidative process produced by frying in the presence of metallic recipients. 
Table 2 - Influence of the frying recipients on the Iodine Index values (II) of soy (Glycine max) and refined nhandiroba (Fevillea trilobata) oils.

\begin{tabular}{llccccc}
\hline & & \multicolumn{5}{c}{ Iodine Index $\left(\mathbf{g} \mathbf{I}_{\mathbf{2}} / \mathbf{1 0 0 g}\right.$ oil $)$} \\
\hline \multicolumn{1}{c}{ Refineds Oils } & Recipients & $\mathbf{0 h}$ & $\mathbf{8 h}$ & $\mathbf{2 4 h}$ & $\mathbf{4 8 h}$ & $\mathbf{7 2 h}$ \\
\hline \multirow{3}{*}{ Soy } & Glass & 109.10 & 98.40 & 87.00 & 73.00 & 50.00 \\
(Glycine max $)$ & Aluminium & 102.00 & 92.00 & 86.00 & 62.00 & 48.00 \\
& Iron & 100.00 & 89.00 & 69.50 & 58.00 & 47.00 \\
& Stainless steel & 99.80 & 78.00 & 66.00 & 50.00 & 45.00 \\
Nhandiroba & Glass & 103.40 & 97.10 & 96.40 & 87.00 & 74.00 \\
(Fevillea trilobata $)$ & Aluminium & 101.10 & 96.00 & 96.10 & 83.50 & 72.00 \\
& Iron & 110.20 & 110.20 & 71.00 & 71.00 & 69.00 \\
& Stainless steel & 110.68 & 85.99 & 76.00 & 75.70 & 70.08 \\
\hline
\end{tabular}

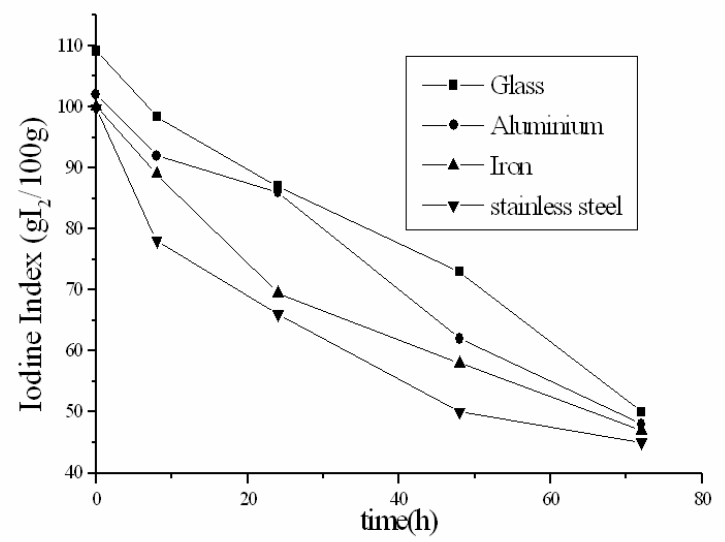

Figure 3 - Influence of the type of frying recipients on the II of the soy oil.

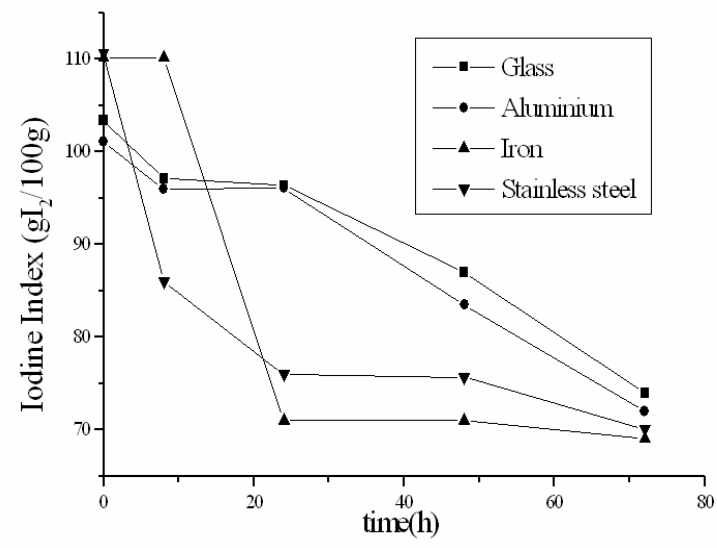

Figure 4 - Influence of the type of frying recipients on the II of the nhandiroba oil. 
Table 3 - Influence of the frying recipients on the Peroxide Index values (PI) of soy (Glycine max) and refined nhandiroba (Fevillea trilobata) oils.

\begin{tabular}{clccccc}
\hline & \multicolumn{7}{c}{ Peroxide Index (mequiv / kg óleo) } \\
\hline Refineds Oils & Recipients & $\mathbf{0 h}$ & $\mathbf{8 h}$ & $\mathbf{2 4 h}$ & $\mathbf{4 8 h}$ & $\mathbf{7 2 h}$ \\
\hline & Glass & 10.00 & 30.00 & 60.00 & 30.00 & 20.00 \\
Soy (Glycine max) & Aluminium & 30.00 & 40.00 & 80.00 & 30.00 & 30.00 \\
& Iron & 40.00 & 100.00 & 120.00 & 30.00 & 20.00 \\
& Stainless steel & 40.00 & 80.00 & 100.00 & 30.00 & 30.00 \\
Nhandiroba & Glass & 30.00 & 50.00 & 60.00 & 30.00 & 30.00 \\
(Fevillea trilobata) & Aluminium & 40.00 & 60.00 & 60.00 & 40.00 & 40.00 \\
& Iron & 40.00 & 70.00 & 60.00 & 40.00 & 40.00 \\
& Stainless steel & 50.00 & 60.00 & 50.00 & 40.00 & 40.00 \\
\hline
\end{tabular}

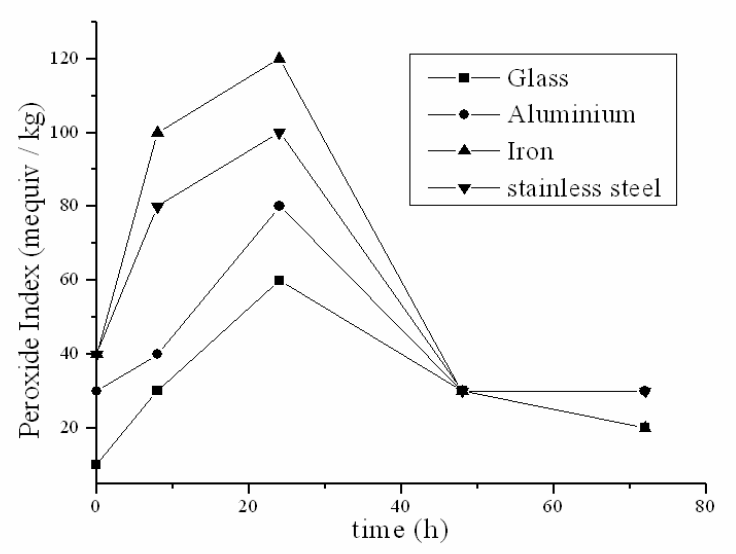

Figure 5 - Influence of the type of frying recipients on the PI of the soy oil.

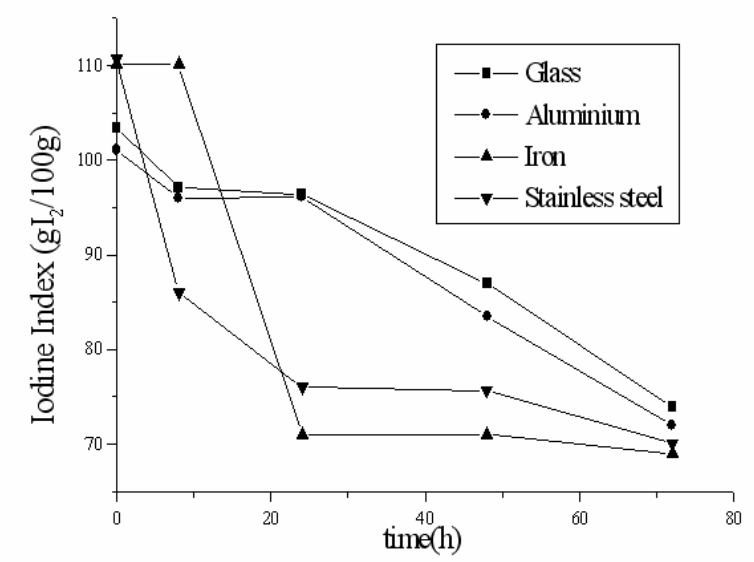

Figure 6 - Influence of the type of frying recipients on the nhandiriba oil. 
In 2005, Ravi in his work on oil blends during frying food, observed alterations in the intensity of red and yellow colors during the heating process of oils. Table 4 and Figures 7 - 12 display increasing red units of the color measurement of oils during the time interval of $72 \mathrm{~h}$ of heating, while yellow units presented the highest degree of growth in all the samples. At the end of the process, in other words, $72 \mathrm{~h}$ of frying, it was observed that the blue units did not contribute for the darkening of the oil. The neutral unit presented a slight growth from the $24 \mathrm{~h}$ of cooking onwards.

Table 4 - Influence of the frying recipients on the color units of soy (Glycine max) and refined nhandiroba (Fevillea trilobata) oils.

\begin{tabular}{|c|c|c|c|c|c|c|c|c|c|c|c|c|c|c|c|c|}
\hline \multirow[b]{3}{*}{ Refineds oils } & \multirow[b]{3}{*}{ Recipients } & \multicolumn{15}{|c|}{ Time Of Frying /Color The Oils } \\
\hline & & \multicolumn{3}{|c|}{$\mathbf{0 h}$} & \multicolumn{3}{|c|}{$8 \mathbf{h}$} & \multicolumn{3}{|c|}{$24 \mathrm{~h}$} & \multicolumn{3}{|c|}{$48 \mathrm{~h}$} & \multicolumn{3}{|c|}{$72 \mathrm{~h}$} \\
\hline & & $\mathbf{R}$ & $\mathbf{Y}$ & $\mathbf{N}$ & $\mathbf{R}$ & $\mathbf{Y}$ & $\mathbf{N}$ & $\mathbf{R}$ & $\mathbf{Y}$ & $\mathbf{N}$ & $\mathbf{R}$ & $\mathbf{Y}$ & $\mathbf{N}$ & $\mathbf{R}$ & $\mathbf{Y}$ & $\mathbf{N}$ \\
\hline \multirow{4}{*}{$\begin{array}{l}\text { Soy } \\
\text { Glycine max }\end{array}$} & Glass & 0.1 & 0.4 & 0.0 & 0,1 & 0.6 & 0.1 & 0.1 & 1.2 & 0.1 & 3.0 & 39 & 0.9 & 4.0 & 39 & 1.0 \\
\hline & Aluminium & 0.1 & 0.5 & 0.0 & 0,1 & 0.8 & 0.1 & 0.1 & 1.6 & 0.1 & 4.0 & 39 & 1.0 & 0.6 & 7.0 & 0.1 \\
\hline & Iron & 0.1 & 0.4 & 0.0 & 0,4 & 3.0 & 0.1 & 0.8 & 10 & 0.6 & 8.2 & 70 & 1.1 & 9.2 & 70 & 1.1 \\
\hline & Stainless steel & 0.1 & 0.6 & 0.0 & 0,5 & 9.0 & 0.1 & 1.5 & 15 & 0.8 & 9.0 & 70 & 1.1 & 10 & 98 & 1.1 \\
\hline \multirow{4}{*}{$\begin{array}{l}\text { Nhandiroba } \\
\text { Fevillea } \\
\text { trilobata }\end{array}$} & Glass & 0.7 & 2.5 & 0.1 & 0,7 & 3.5 & 0.1 & 1.0 & 5.0 & 0.1 & 6.1 & 7.0 & 0.6 & 6.1 & 22 & 0.8 \\
\hline & Aluminium & 0.7 & 3.2 & 0.1 & 0,8 & 7.0 & 0.1 & 1.1 & 9.8 & 0.1 & 6.2 & 7.0 & 0.8 & 3.1 & 46 & 0.8 \\
\hline & Iron & 0.7 & 2.5 & 0.1 & 0,8 & 7.3 & 0.1 & 2.1 & 22 & 0.6 & 0.9 & 70 & 0.9 & 3.5 & 96 & 0.8 \\
\hline & Stainless steel & 0.7 & 2.7 & 0.1 & 0,9 & 7.5 & 0.1 & 4.3 & 70 & 0.8 & 6.7 & 70 & 1.0 & 8.7 & 96 & 0.8 \\
\hline
\end{tabular}

R(red), Y(yellow), N(neutral).

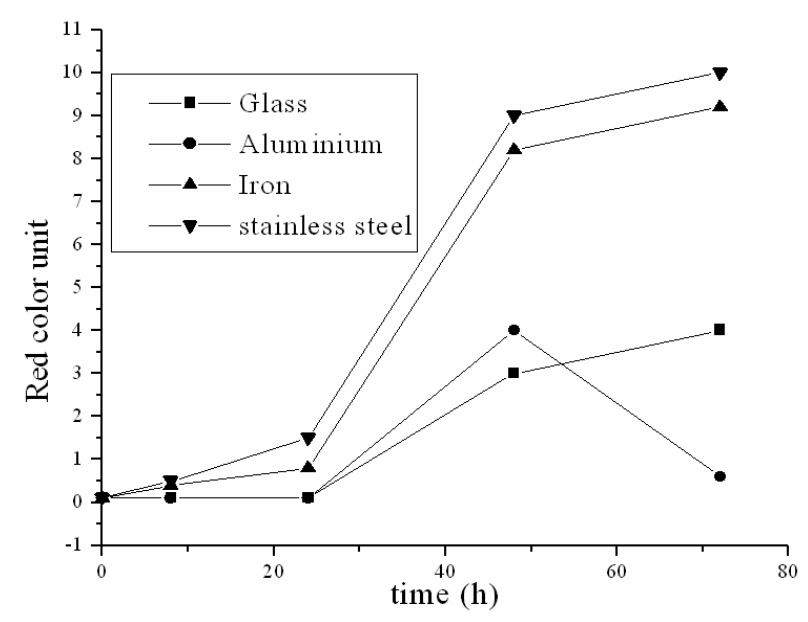

Figure 7 - Influence of the type of frying recipients on the red color until of the soy oil. 


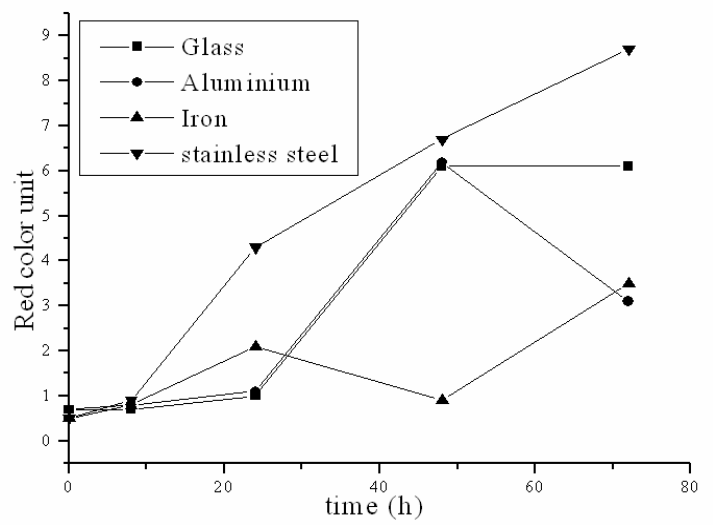

Figure 8 - Influence of the type of frying recipients on the red color until of the nhandiroba oil.

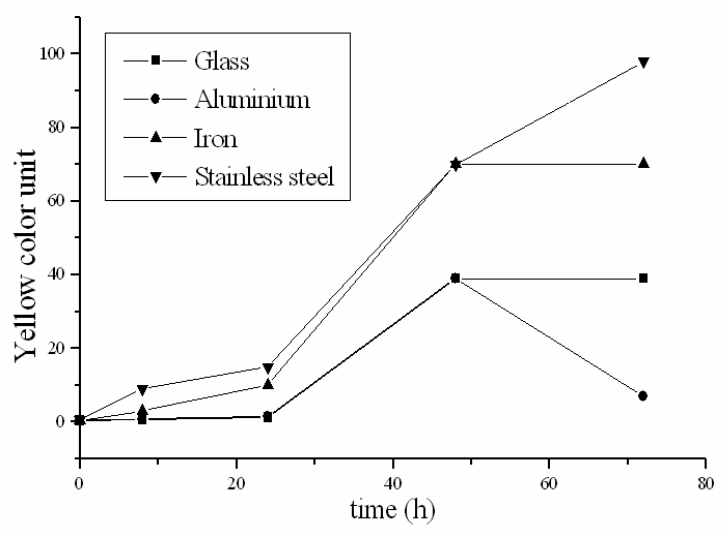

Figure 9 - Influence of the type of frying recipients on the yellow color until of the soy oil.

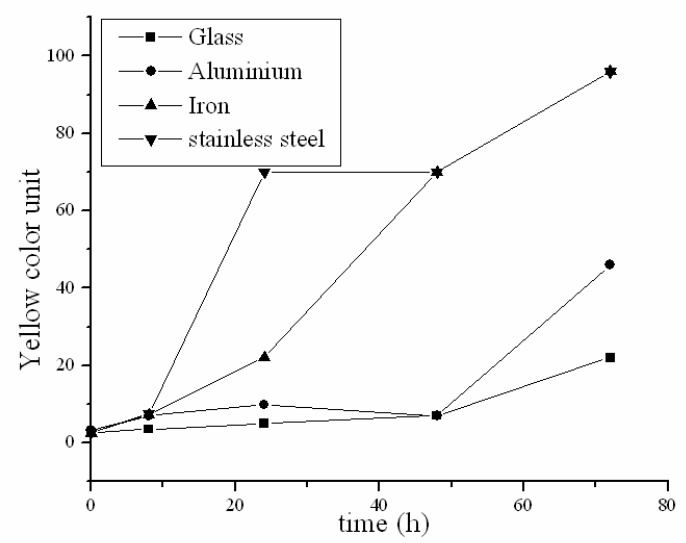

Figure 10 - Influence of the type of frying recipients on the yellow color until of the nhandiroba oil. 


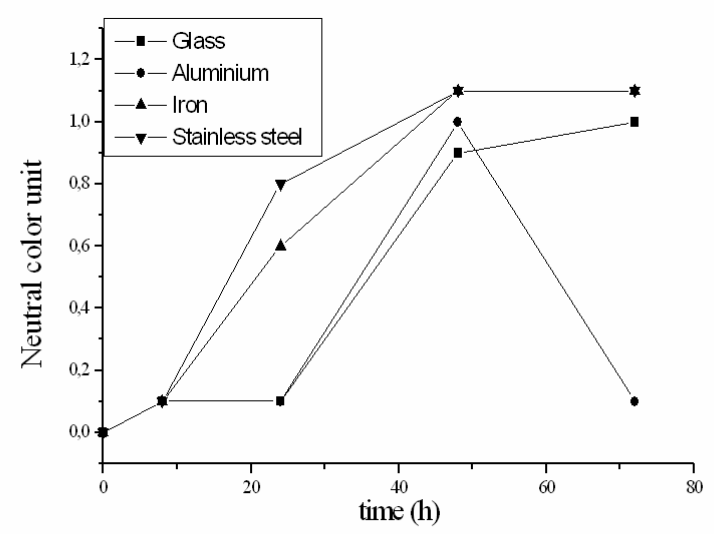

Figure 11 - Influence of the type of frying recipients on the neutral color until of the soy oil.

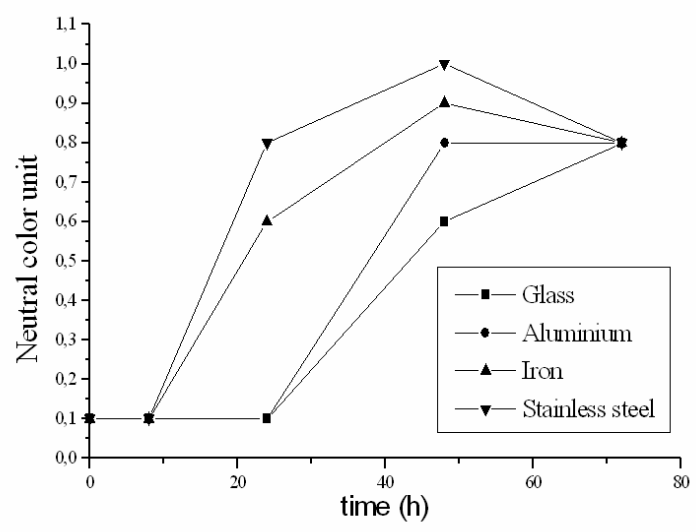

Figure 12 - Influence of the type of frying recipients on the neutral color until of the nhandirob oil.

The soy oil during the $72 \mathrm{~h}$ treatment in the glass recipients presented significant variations in the red color unit, modifying from 0.1 to $4.0(4000 \%)$, whereas the nhandiroba oil presented a smaller variation, from 0.7 to $6.0(600 \%)$. In the aluminium recipient, the nhandiroba oil after a heating period of $48 \mathrm{~h}$ altered from 0.7 to $6.2 \mathrm{but}$ soon afterwards it reduced to 3.1 in $72 \mathrm{~h}$. In that recipient, the soy oil modified from 0.1 to 4.0 after $48 \mathrm{~h}$ of frying, reducing to $0.6 \mathrm{in} 72 \mathrm{~h}$. The frying with soy oil in the stainless steel recipient during the same period led to a higher darkening than the nhandiroba oil. The red color unit moved from 0.1 to 10 (alteration of $9900 \%$ ). In that period the nhandiroba oil passed from 0.7 to 8.7 (1142\%). The frying of the soy oil in the iron recipient altered the red units from 0.7 to 96 (13600\%), while the soy oil in that recipient changed from 0.1 to $70(69900 \%)$. Those color alterations of the oils in terms of red color units were accompanied by significant alterations in yellow color units. The neutral unit color presented variations that were not significant, whereas the blue unit color was not detected during the frying process. For the two oils, the frying process for $72 \mathrm{~h}$ propitiated an increase in the yellow intensity of $7400 \%$ for the soy oil and of $1740 \%$ for the nhandiroba oil. In the work of Quintaes (2004), migrations of inorganic components such as $\mathrm{Fe}, \mathrm{Mg}, \mathrm{Mn}, \mathrm{Cr}, \mathrm{Ni}, \mathrm{Ca}$ and $\mathrm{Zn}$ from stainless steel, cast iron and soapstone (steatite) cookery recipients to food simulators were observed. In the present work, the migration of iron and aluminium ions from iron, stainless steel, aluminium and glass frying recipients was progressive during the oxidative process of oils (Table 5 and Fig. 13 and 14). This study confirmed that iron recipients exerted more influence on the oxidative process of oils than the aluminium recipients during the frying process. 
Table 5 - Migration of Fe and Al ions to soy (Glycine max) and refined nhandiroba (Fevillea trilobata) oils during frying

\begin{tabular}{lclccccc}
\hline \multicolumn{7}{c}{ Concentration ions $(\boldsymbol{\mu g} / \mathbf{m L}) /$ Time $(\mathbf{h})$} \\
\hline \multicolumn{1}{c}{ Refineds Oils } & Ion & Recipient & $\mathbf{0}$ & $\mathbf{8}$ & $\mathbf{2 4}$ & $\mathbf{4 8}$ & $\mathbf{7 2}$ \\
\hline \multirow{2}{*}{ Soy } & \multirow{2}{*}{ Fe } & Stainless steel & 3.00 & 4.40 & 6.50 & 8.70 & 12.00 \\
(Glycine max) & Iron & 4.00 & 5.20 & 7.20 & 9.90 & 14.00 \\
Nhandiroba & $\mathrm{Al}$ & Aluminium & 0.10 & 0.10 & 0.16 & 0.20 & 0.20 \\
(Fevillea & & Stainless steel & 2.00 & 3.30 & 5.10 & 7.00 & 8.00 \\
trilobata $)$ & $\mathrm{Fe}$ & Iron & 2.40 & 3.70 & 6.00 & 9.00 & 11.00 \\
& $\mathrm{Al}$ & Aluminium & 0.10 & 0.10 & 0.20 & 0.25 & 0.30 \\
\hline
\end{tabular}

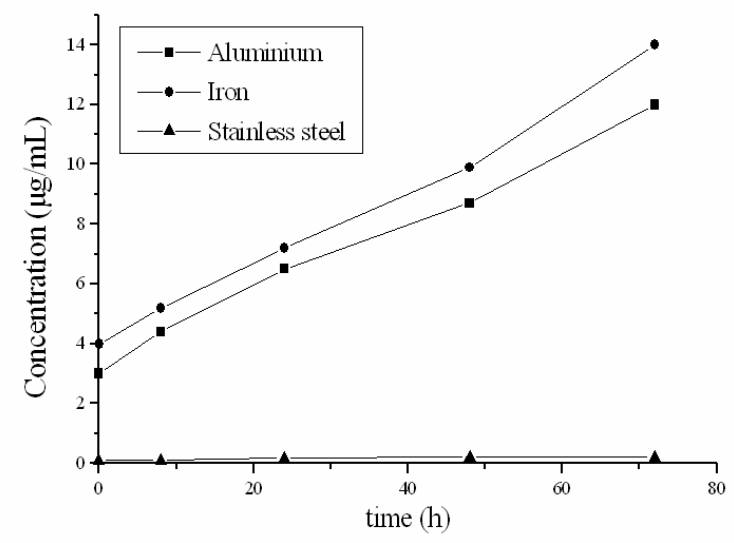

Figure 13 - Migration of $\mathrm{Fe}$ and $\mathrm{Al}$ ions to soy oil during frying.

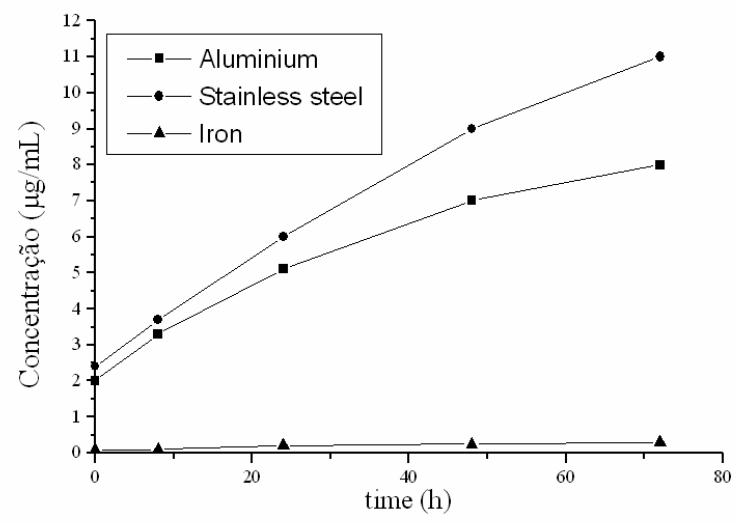

Figure 14 - Migration of $\mathrm{Fe}$ and $\mathrm{Al}$ ions to refined nhadiroba oil during frying.

\section{CONCLUSION}

The effect of the types of frying recipients on the oxidative stability of frying oils was observed through the increase in the FFA values (for Soy oil) and decrease in the FFA values (for refined nhandiroba oil), increase in the PI and decrease in the II when stainless steel, iron aluminium and glass recipients were used. The degradation effect observed in both the oils was higher in the 
presence of the iron metal. The migration of ions increased with the time of frying, causing oxidation in the oils. The aluminium recipient presented higher oxidation in the oils when compared to glass recipients. The refined nhandiroba oil was the most resistant to the thermo-oxidation effects during the frying process in all the recipients. Therefore, the most indicated recipient for frying food was the glass recipient. The vegetable oils become darker with the frying process, but, the recipients contributed significantly for these alterations and vary in such a way that they can interfere in the quality of food and, consequently in the organoleptic properties of the final product of the frying.

\section{RESUMO}

O Objetivo fundamental foi quantificar a migração dos íons ferro, alumínio e avaliar a influencia dos recipientes de inox, de ferro, de alumínio e de vidro no processo de estabilidade oxidativo, durante a fritura em óleos refinados de soja (Glycine max) e de nhandiroba (Fevillea trilobata). O óleo de Soja durante o processo de fritura nos quatro tipos de recipientes apresentou valores aumentados de (AGL) e (IP) e valores diminuídos (II). O óleo de nhandiroba refinado apresentou taxas de (AGL) decrescidas nos recipientes pesquisados. As análises dos resultados mostraram que o óleo de soja apresentou alterações oxidativas relevantes, quando comparado com o tempo de aquecimento de 72 horas e os tipos de recipientes de frituras utilizados, sendo que, em recipientes de ferro e inox essas diferenças foram maiores do que em recipientes de alumínio e vidro. As análises do óleo de nhandiroba apresentaram modificações oxidativas brandas nos quatro tipos de recipientes pesquisados.

\section{REFERENCES}

Association of Official Analytical Chemists - AOAC. (2000), Official methods of analysis. 17.ed Washington, DC. 1094p.

Che Man, Y. B. and Jaswir, I. (1999), Effect of rosemary and sage extracts on frying performance of refined, bleached and deodorized (RDB) palm olein during deep-fat frying. Food Chemistry. 69, 301-307.

Gião, A. N. S. V.; Mattos, E. S. and Jorge, N. (1999),
Avaliação da qualidade dos óleos de fritura usados em restaurantes, lanchonetes e similares. Ciência e Tecnologia de Alimentos, 19(3), 1-15.

Mogharbel, A. D. I. and Freitas, R. J. S. (2003), Influência do aquecimento nos meios de fritura sobre o grau de acidez e índice de iodo. Brasil Alimentos. 20, 35-37.

Moharram, Y. G and Osman, H. O. A. (1982), Some changes in cottonseed oil during frying of flafel and eggplant. Food Chemistry. 9(3), 159-165.

Ndjouenkeu, R. and Ngassoum, M. (2002), Etude comparative de la valeur em friture de quelques huiles vegetales. J. of Food Engineering. 52, 121125.

Ogunsua, A. O. and Badifu, G. I. (1989), Stability of purified Melon seed oil obtained by solvent extraction. J. Food Sci. 54(1), 71-73.

Paul, S. and Mittal, G.S. (1997), Regulating the use of degraded oil/fat in deep-fat/oil food frying. Critical Reviews in food science and Nutrition, 37(7), 635662.

Quintaes, K. D.; Amaya-Farfan, J.; Tomazini, F. M.; Morgano, M. A. and Mantovani, D. M. B. (2004), Migração de minerais de panelas brasileiras de aço inoxidável, ferro fundido e pedra sabão (esteatito) para simulantes de alimentos. Ciência e Tecnologia de Alimentos. 24 (3), 397-402.

Ravi, R.; Prakash, M. and Bhat, K. K. (2005), Sensory odour profilin and physical characteristic of edible oil

blends during frying. Food Research International. 38, 59-68.

SAS INSTITUTE. (2003), Statistic Analyses Systems (User's guide: statistics). Version 8.0, 6ed., Cary: 300p.

Yaghmur, A.; Aserin, A.; Mizrahi, A.; Nerd, A. and Garti, N. (2001), Evaluation of argan oil for deep-fat frying. LWT. 34, 124-130.
Received: March 28, 2006; Revised: June 11, 2007; Accepted: November 19, 2008. 